\title{
Protective effects of Ficus carica seed oil on ischemia and reperfusion injury in a rat model of acute mesenteric ischemia
}

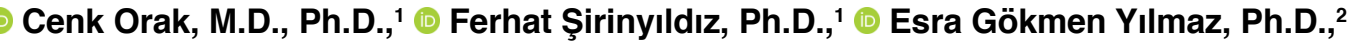 \\ Gökhan Cesur, Ph.D., ${ }^{1}$ Rauf Onur Ek, M.D., Ph.D.1
}

\author{
${ }^{1}$ Department of Physiology, Aydın Adnan Menderes University Faculty of Medicine, Aydın-Turkey \\ ${ }^{2}$ Department of Histology and Embryology, Aydın Adnan Menderes University Faculty of Medicine, Aydın-Turkey
}

\begin{abstract}
BACKGROUND: The increase in free oxygen radicals and proinflammatory cytokines in the ischemia-reperfusion injury caused by acute mesenteric ischemia are the key responsibilities of intestinal histopathological alterations. It has been reported that Ficus carica and its various parts contain antioxidant and anti-inflammatory compounds recently. Thus, in the present study, we aimed to investigate how Ficus carica seed oil affects intestinal ischemia-reperfusion injury in a rat model.

METHODS: In this study, 50 male Wistar albino rats were randomly divided into five equal groups. Negative control (NC), sham-operated (Sham), ischemia and reperfusion (IR), $3 \mathrm{ml} / \mathrm{kg} /$ day Ficus carica seed oil (FC3), $6 \mathrm{ml} / \mathrm{kg} /$ day Ficus carica seed oil (FC6). IR, FC3 and FC6 groups underwent ischemia and reperfusion procedure for $45+120 \mathrm{~min}$. Only abdominal midline laparotomy was performed in the Sham group for 165 minutes.
\end{abstract}

RESULTS: Tissue levels of TNF $\alpha$ and IL-1 $\beta$, which were proinflammatory cytokines, were significantly reduced in the FC6 group than the IR group $(p<0.05)$. In FC3 and FC6 groups, the tissue MPO and MDA enzyme levels were significantly lower than the IR group, but there was a significantly greater decrease in the FC6 group than the FC3 group $(p<0.05)$. SOD and CAT enzymes and reduced glutathione levels of FC3 and FC6 groups were significantly lower than IR group $(p<0.05)$; however, there was no statistically significant difference between the FC3 and FC6 groups. FC3 and FC6 groups were histopathologically graded statistically lower than the IR group, and the FC6 group showed a significant decrease than the FC3 group $(p<0.05)$.

CONCLUSION: Oral administration of fig seed oil may reverse biochemical and histopathological findings resulting from ischemia-reperfusion injury in an experimental model of acute mesenteric ischemia in rats, probably because of its antioxidant and anti-inflammatory compounds.

Keywords: Acute mesenteric ischemia; antioxidant; Ficus carica; ischemia-reperfusion injury.

\section{INTRODUCTION}

Intestinal ischemia is a life-threatening syndrome that has three main subclasses as follows: acute mesenteric ischemia (AMI), chronic mesenteric ischemia (intestinal angina) and colonic ischemia (ischemic colitis). ${ }^{[1]}$ AMI, which accounts for about I:1000 emergency service admissions in Europe and the USA, is a large complex of diseases that includes acute mesenteric arterial embolism (50\%) and thrombus (15-25\%), mesenteric venous thrombus (5-15\%) and non-occlusive mesenteric ischemia (20\%). ${ }^{[2]}$ Despite advanced radiological and surgical methods, effective antibiotherapy and early diagnosis, mesenteric ischemia is a highly mortal disorder for decades. Although it constitutes only $\mathrm{I}-2 \%$ of all gastrointestinal diseases, its mortality rates vary between $30 \%$ and $90 \%$, even undiagnosed $\mathrm{AMI}$ is ignored. ${ }^{[3,4]}$

Cite this article as: Orak C, Şirinyıldız F, Gökmen Yılmaz E, Cesur G, Ek RO. Protective effects of Ficus carica seed oil on ischemia and reperfusion injury in a rat model of acute mesenteric ischemia. Ulus Travma Acil Cerrahi Derg 2021;27:402-409.

Address for correspondence: Cenk Orak, M.D.

Aydın Adnan Menderes Üniversitesi Tıp Fakültesi, Fizyoloji Anabilim Dalı, Aydın, Turkey

Tel: +90256 - 2182000 E-mail: cenk.orak@adu.edu.tr

Ulus Travma Acil Cerrahi Derg 2021;27(4):402-409 DOI: 10.14744/tjtes.2020.76767 Submitted: 31.10.2019 Accepted: 10.05.2020

Copyright 2021 Turkish Association of Trauma and Emergency Surgery 
AMI results from total disruption or critical reduction in blood flow due to embolic, thrombotic or nonocclusive causes. The most common etiological cause is superior mesenteric artery embolism and thrombosis. ${ }^{[4,5]}$ Ischemia due to occlusion of the superior mesenteric artery causes cellular damage, necrosis and organ dysfunction may be followed by death. ${ }^{[6]}$

Disruption of the blood flow causes ischemic injury and then reperfusion of the tissue initiates a cascade of events that result in paradoxically more cellular damage, which is known as reperfusion injury. ${ }^{[7]}$ The cellular damage that arises from ischemia-reperfusion is due to increased activation of radicals, various cytokines, chemokines, endothelins, proteases and phospholipases, changes in calcium concentration, ATP consumption and inhibition of nitric oxide synthesis. ${ }^{\left[{ }^{[8]}\right.}$ However, it has been reported that reactive oxygen metabolites are the main responsible for tissue damage in intestinal ischemia-reperfusion injury. ${ }^{[9]}$ The small intestine is one of the most susceptible organs to ischemia and reperfusion (IR) injury that leads to altered permeability of the small intestinal mucosa, bacterial translocation and consequently endotoxemia. ${ }^{[10]}$

Ficus carica, a species of tree from the Moraceae family, is one of the oldest known agricultural products in the Mediterranean region. Figs (Ficus carica fruits), which are a part of the Mediterranean type diet, are consumed quite frequently in this region. It has been reported that figs have a high antioxidant capacity due to their polyphenolic compounds and especially anthocyanins, which reduce the cellular damage caused by free radicals. ${ }^{[1,12]}$ In recent studies, phytochemicals in Ficus carica (e.g., phenolic compounds, anthocyanins, phytosterols, amino acids, organic acids and fatty acids) have been shown to have anticarcinogenic, hypolipidemic, anti-inflammatory and antioxidant properties. ${ }^{[13,14]}$ This study aimed to test the efficacy of cold-pressed Ficus carica seed oil against intestinal ischemia-reperfusion injury due to occlusion of the superior mesenteric artery in rats to investigate possible prophylactic use of it in preventing intestinal mucosal damage.

\section{MATERIALS AND METHODS}

\section{Animals}

All the animal experiments were approved by the local ethic committee of animal experimentation at Aydın Adnan Menderes University, Turkey. 50 male Wistar albino rats (weighing 200-250 gr/3 months old) were obtained from Aydın Adnan Menderes University Center of Laboratory Animals, Turkey. Rats were kept under standard conditions $\left(24^{\circ} \mathrm{C}, 60 \pm 10 \%\right.$ relative humidity and a $12 \mathrm{~h}$ light dark cycle), fed ad libitum standard pellet and allowed free access to tap water.

\section{Experimental Design}

Rats were divided into five equal groups as follows: negative control (NC), sham-operated (Sham), ischemia and reperfusion (IR), $3 \mathrm{ml} / \mathrm{kg} /$ day Ficus carica seed oil (FC3) and $6 \mathrm{ml} /$ $\mathrm{kg} /$ day Ficus carica seed oil (FC6). The rats in the FC3 group were given $3 \mathrm{ml} / \mathrm{kg} /$ day and the rats in the $\mathrm{FC} 6$ group were given $6 \mathrm{ml} / \mathrm{kg} / \mathrm{day}$ fig seed oil (purchased from local manufacturer Oneva ${ }^{\circledR}$ Istanbul, TURKEY) via gastric gavage for 10 days before the ischemia and reperfusion procedure.

All the rats were not allowed to feed except tap water 12 hours before the operation and then anesthetized by intraperitoneal injection of ketamine $50 \mathrm{mg} / \mathrm{kg}$ (Ketalar ${ }^{\circledR}$; Parke Davis, Eczacibasi, Istanbul, Turkey) and xylazine $10 \mathrm{mg} / \mathrm{kg}$ (Rompun'; Bayer AG, Leverkusen, Germany). In IR, FC3 and FC6 groups after abdominal midline laparotomy, SMA was dissected carefully and occluded via an atraumatic microvascular clamp for 45 minutes (ischemia period). To ensure that the ischemia period began, the nonexistence of the pulsation of SMA was palpated and intestinal pallor was observed. Then, the clamp was removed and a 120 min reperfusion period began. Reperfusion was recognised by the pulses on SMA and the existence of pallor of intestines. Only abdominal midline laparotomy was performed in the NC group and then tissue samples were immediately collected. In the Sham group, after abdominal midline laparotomy, SMA was dissected but not occluded then tissue samples were collected at the end of the 165 minutes. For histopathological and biochemical analyses, the last $10 \mathrm{~cm}$ of the small intestine was removed then separated into two equal parts. All the rats were euthanized with high-dose anesthesia.

\section{Histopathological Evaluation}

All small intestine specimens were fixed in $10 \%$ formaldehyde solution. After dehydration in ascendant alcohol series, clearing in xylene and paraffinization, the tissues are embedded in paraffin blocks. Tissue blocks were randomly cut into $4 \mu \mathrm{m}$ sections by microtome (Leica ${ }^{\circledR}$ RM2I35) and deparaffinized. The sections were stained Hematoxylin-Eosin (Cat. No. 0506002/L, 05-10003/L Bio-Optica ${ }^{\circledR}$, Milan, Italy), Periodic Acid Shiff Hotchkiss-Mc Manus (Cat. No. 04-130802, Bio-Optica ${ }^{\circledR}$, Milan, Italy), Masson Trichromee with Anilin Blue (Cat. No. 04-010802, Bio-Optica ${ }^{\circledR}$, Milan, Italy) according to the instructions of the manufacturer.

Histopathological grading was performed by a histopathologist as described by Chiu et al... ${ }^{[5]}$ Mucosal damage was graded on a scale from 0 to 5 : grade 0 , normal mucosa; grade I, subepithelial Gruenhagen's space at the top of the villus; grade 2, Extension of the Gruenhagen's space and moderate lifting of epithelial layer; grade 3 massive lifting of the epithelial layer and a few denuded villi; grade 4, denuded villi with dilated capillaries; grade 5, digestion of mucosal layer hemorrhage, and ulceration.

\section{Biochemichal Analyses}

Each small intestinal tissue specimen was washed with $0.9 \%$ $\mathrm{NaCl}$ then homogenized in $50 \mathrm{mM}$ phosphate buffer $\mathrm{pH} 7.0$ at $4^{\circ} \mathrm{C}$. The homogenates were centrifuged at $15000 \mathrm{rpm}$ 
Table I. Biochemical parameters

\begin{tabular}{|c|c|c|c|c|c|c|c|}
\hline & $\begin{array}{c}\text { TNF } \alpha \\
\text { (pg/g tissue) }\end{array}$ & $\begin{array}{c}\text { IL-I } \beta \\
\text { (pg/g tissue) }\end{array}$ & $\begin{array}{c}\text { MPO } \\
\text { (U/g tissue) }\end{array}$ & $\begin{array}{c}\text { MDA } \\
\text { (nmol/g tissue) }\end{array}$ & $\begin{array}{c}\text { GSH } \\
\text { ( } \mu \mathrm{mol} / \mathrm{g} \text { tissue) }\end{array}$ & $\begin{array}{c}\text { SOD } \\
\text { (U/mg tissue) }\end{array}$ & $\begin{array}{c}\text { CAT } \\
\text { (U/g tissue) }\end{array}$ \\
\hline NC & $1305( \pm 83.17)^{\mathrm{a}}$ & I I $70( \pm 86.79)^{\mathrm{a}}$ & $417.20( \pm 25.25)^{\mathrm{a}}$ & $51.50( \pm 4.28)^{\mathrm{a}}$ & $0.91( \pm 0.05)^{\mathrm{a}}$ & $31.3( \pm 2.5)^{\mathrm{a}}$ & $5.53( \pm 0.32)^{\mathrm{a}}$ \\
\hline Sham & $1313( \pm 121.11)^{\mathrm{a}}$ & $1189( \pm 83.33)^{\mathrm{a}}$ & $452.40( \pm 46.95)^{\mathrm{a}}$ & $51.30( \pm 4.92)^{\mathrm{a}}$ & $0.97( \pm 0.04)^{\mathrm{a}}$ & $31.7( \pm 2.3 \mathrm{I})^{\mathrm{a}}$ & $5.14( \pm 0.16)^{\mathrm{a}}$ \\
\hline IR & $1726( \pm 136.48)$ & $|8| \mid( \pm 82.52)$ & $875.10( \pm 64.78)$ & $79.70( \pm 7.07)$ & $0.70( \pm 0.08)$ & $24.5( \pm 2.80)$ & $4.79( \pm 0.09)$ \\
\hline FC3 & $|57|( \pm \mid 45.56)$ & $1484( \pm 100.35)^{a}$ & $776.90( \pm 65.13)^{\mathrm{a}}$ & $72.00( \pm 5.1)^{\mathrm{a}}$ & $1.16( \pm 0.12)^{\mathrm{a}}$ & $30.5( \pm 3.24)^{\mathrm{a}}$ & $5.02( \pm 0.05)^{\mathrm{a}}$ \\
\hline FC6 & $1527( \pm 133.09)^{\mathrm{a}}$ & $1390( \pm 84.72)^{\mathrm{a}}$ & $704.70( \pm 53.15)^{a, b}$ & $65.10( \pm 5.26)^{\mathrm{a}, \mathrm{b}}$ & $1.23( \pm 0.11)^{\mathrm{a}}$ & $31.60( \pm 1.84)^{\mathrm{a}}$ & $5.02( \pm 0.1)^{\mathrm{a}}$ \\
\hline
\end{tabular}

The results are presented as mean $( \pm \mathrm{SD})$. $\mathrm{a}<<0.05$ vs. IR, ${ }^{\mathrm{b}} \mathrm{p}<0.05$ vs. FC3. TNF- $\alpha$ : Tumor necrosis factor-alpha; IL-I $\beta$ : Interleukin-I lbeta; MPO: Myeloperoxidase; MDA: Malondialdehyde; GSH: Glutathione; SOD: Superoxide dismutase; CAT: catalase; NC: negative control; Sham: Sham-operated; IR: Ischemia and reperfusion; FC: Ficus carica.

for 15 minutes at $4^{\circ} \mathrm{C}$ and the supernatants were used for biochemical analyses.

Tissue myeloperoxidase (MPO) and catalase (CAT) enzyme activities were determined using an MPO colorimetric assay kit (Cat. No. \#K744, BioVision ${ }^{\circledR}$, Milpitas, CA, United States) and a CAT activity colorimetric/fluorometric assay kit (Cat. No. \#K773, BioVision ${ }^{\circledR}$, Milpitas, CA, United States) as described as in the manufacturer's instructions.

For measuring tissue malondialdehyde (MDA) and glutathione levels, a lipid peroxidation (MDA) colorimetric/fluorometric assay kit (Cat. No. \#K739, BioVision ${ }^{\circledR}$, Milpitas, CA, United States) and a glutathione fluorometric assay kit (Cat. No. \#K264, BioVision ${ }^{\circledR}$, Milpitas, CA, United States) were used according to the manufacturer's instructions.

Tissue IL-I $\beta$ and TNF $\alpha$ levels were determined using a rat ILI $\beta$ ELISA kit (Cat. No. EK0393, Sciencell Laboratories ${ }^{\circledR}$, CA, United States) and a rat TNF $\alpha$ ELISA kit (Cat. No. EK0525, Sciencell Laboratories ${ }^{\circledR}, \mathrm{CA}$, United States) according to the manufacturer's instructions.

\section{Statistical Analyses}

The Kolmogorov-Smirnov test was used to investigate whether the quantitative variables were normally distributed. One-way ANOVA test was used to analyze the biochemical data were reported as "mean $( \pm S D)$ " or "(mean $\pm S D)$ ". Kruskal-Wallis nonparametric test were used to analyze the histopathological scores and the results were presented as median (25 percentile-75 percentile). Statistical analyses were performed using GraphPad Prism 6 (GraphPad Software ${ }^{\circledR}$, CA, Unites States). A p-value of less than 0.05 was considered significant.

\section{RESULTS}

\section{Biochemical Parameters}

The results of all biochemical parameters are presented as mean $( \pm S D)$ in Table I. The mean tissue TNF- $\alpha$ level of the IR group was significantly higher than the other groups except the FC3 group $(p<0.05)$. Although the mean of the
FC3 group ( I $57| \pm| 45.56 \mathrm{pg} / \mathrm{g})$ was lower than the IR group

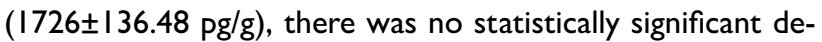
crease. In contrast, the mean TNF- $\alpha$ level of the FC6 group was $1527( \pm 133.09) \mathrm{pg} / \mathrm{g}$ and significantly lower than the IR group $(p<0.05)$ (Fig. I).

The IL-I $\beta$ levels of negative control and sham-operated groups were significantly lower than the IR group $(p<0.05)$.

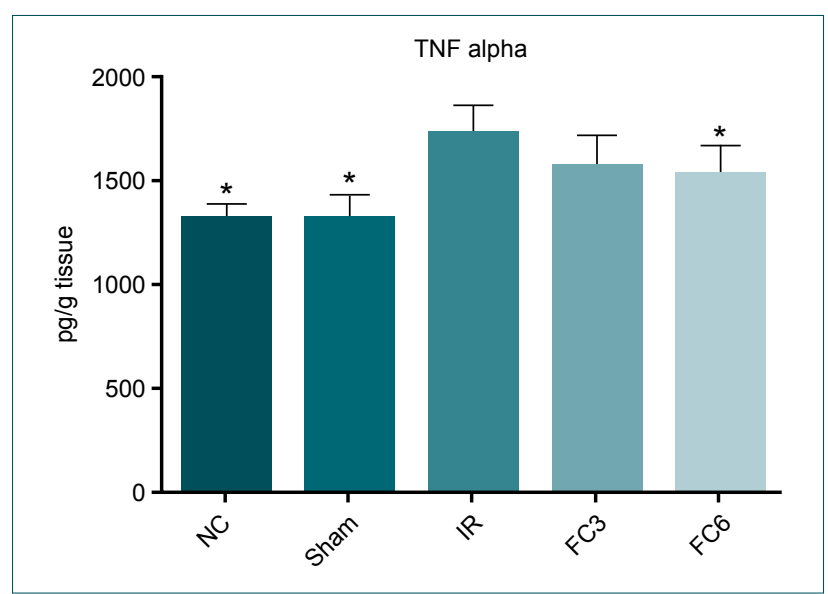

Figure 1. Tissue TNF $\alpha$ levels of all groups. *represents $p<0.05$ vs. IR group.

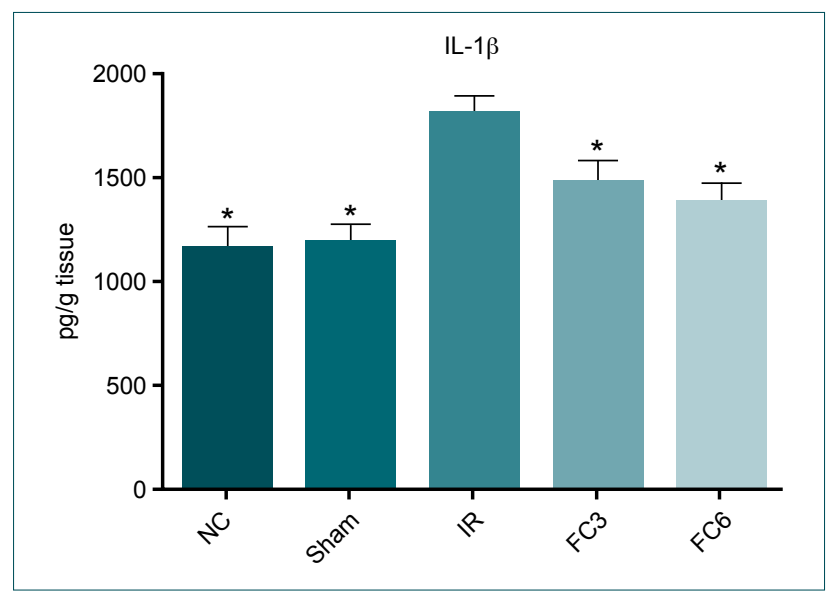

Figure 2. Tissue IL-1 $\beta$ levels of all groups. " represents $p<0.05$ vs. IR group. 
Even if IL- I $\beta$ levels were significantly decreased in the groups which had been administered $3 \mathrm{ml} / \mathrm{kg} /$ day and $6 \mathrm{ml} / \mathrm{kg} /$ day Ficus carica seed oil, there was no significant difference be-

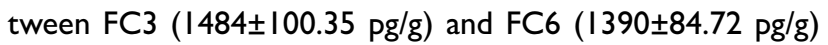
groups (Fig. 2).

In each group, the tissue MPO enzyme levels (Fig. 3) were significantly lower than the IR group $(p<0.05)$. The mean MPO level of the FC6 group was $776.90( \pm 65.13) \mathrm{U} / \mathrm{g}$ and significantly reduced than the FC3 group $(p<0.05)$.

The mean MDA enzyme level of the IR group was statistically increased than all other groups $(p<0.05)$. The MDA levels of each of the FC6 and FC3 groups were lower than the IR group, but there was a significantly greater decrease in the FC6 group than the FC3 group $(p<0.05)$ (Fig. 4).

Mean tissue glutathione level of IR group was significantly lower than all other groups $(p<0.05)$. However, there was no significant difference between FC3 and FC6 groups (Fig. 5).

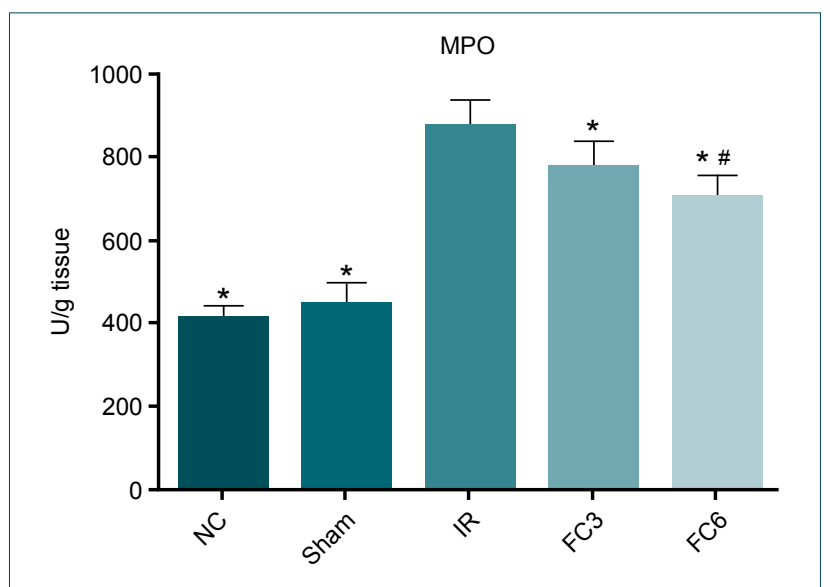

Figure 3. Tissue MPO levels of all groups. *represents $p<0.05$ vs. IR group, "represents $p<0.05$ vs. FC3 group.

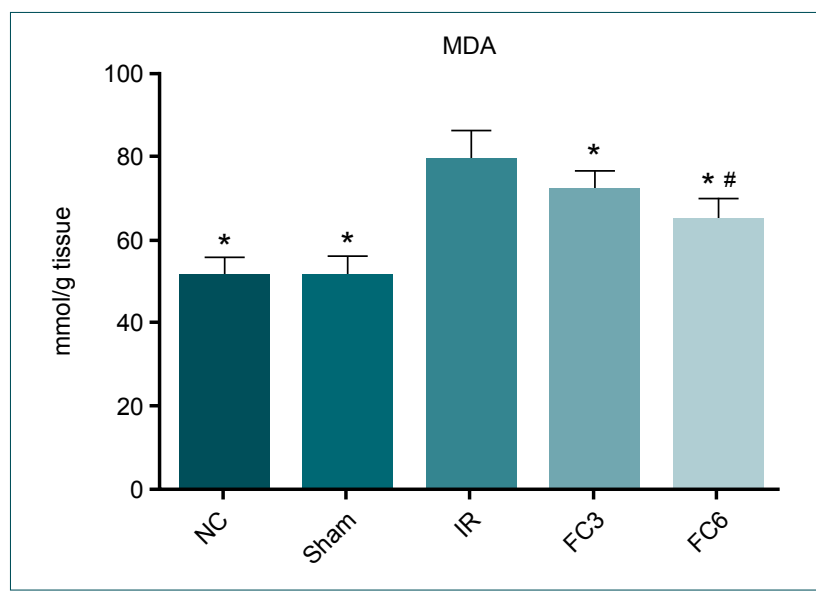

Figure 4. Tissue MDA levels of all groups. *represents $p<0.05$ vs. IR group, "represents $p<0.05$ vs. FC3 group.
Tissue SOD (Fig. 6) and CAT (Fig. 7) enzyme levels of each group were significantly lower than IR group $(p<0.05)$. However, for each of the SOD and CAT enzyme levels, there was no statistically significant difference between the FC3 and FC6 groups.

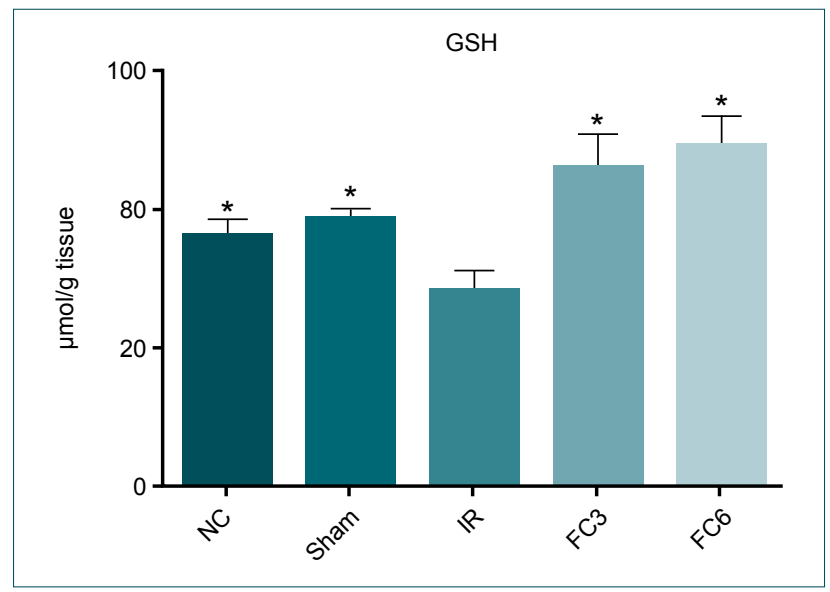

Figure 5. Tissue GSH levels of all groups. " $r e p r e s e n t s ~ p<0.05$ vs. IR group.

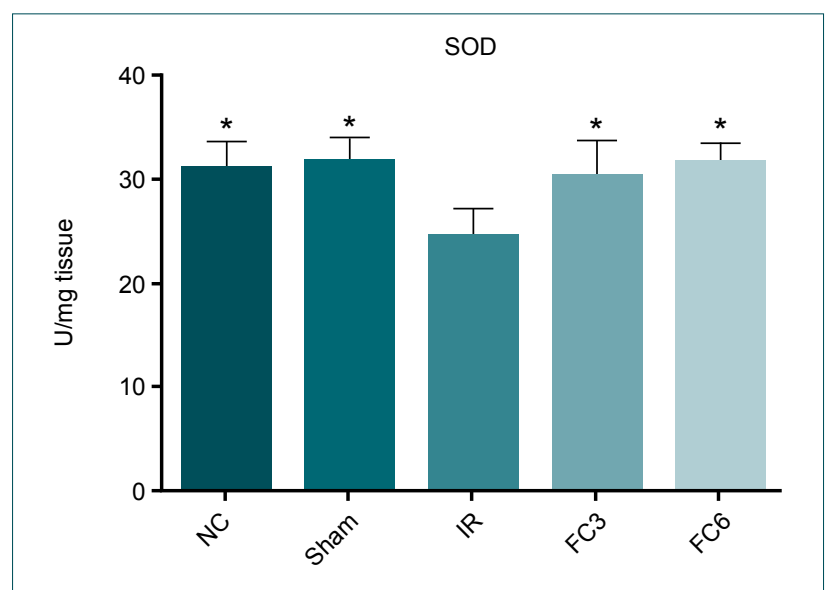

Figure 6. Tissue SOD levels of all groups. *represents $p<0.05$ vs. IR group.

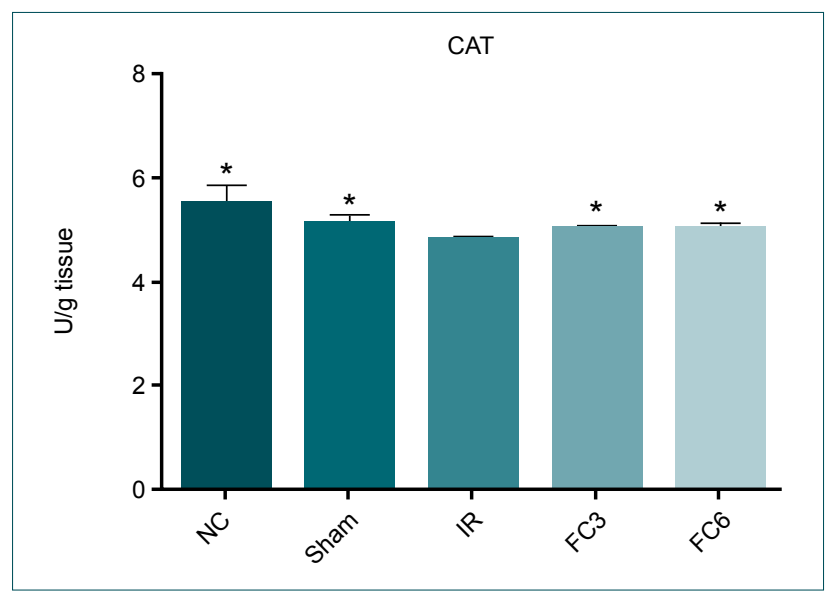

Figure 7. Tissue CAT levels of all groups. "represents $p<0.05$ vs. IR group. 
Table 2. Histopathological grades

\begin{tabular}{lc}
\hline & Grade \\
\hline Negative control & $0(0-0)^{\mathrm{a}}$ \\
Sham-operated & $0(0-0)^{\mathrm{a}}$ \\
Ischemia and reperfusion & $5(5-5)$ \\
Ficus carica3 & $3(3-4)^{\mathrm{a}}$ \\
Ficus carica6 & $\mathrm{I}(\mathrm{I}-\mathrm{I} .25)^{\mathrm{a}, \mathrm{b}}$
\end{tabular}

The results are presented as median ( 25 percentile -75 percentile). ${ }^{\mathrm{a}}<0.05$ vs. IR, ${ }^{\mathrm{b}} \mathrm{P}<0.05$ vs. $\mathrm{FC} 3$.

\section{Histopathological Results}

The histopathological grades of each group are presented as median (25 percentile-75 percentile) in Table 2.

Mucosal layers and the microstructure of villi were intact in the negative control (Fig. 8a-c) and sham-operated groups (Fig. 8d-f). Both sham-operated and negative control groups were evaluated as grade $0(0-0)$ according to Chiu's scoring, and there was no statistically difference between every two groups. In the ischemia and reperfusion group, which was graded 5 (5-5), intestinal mucosa was digested, lamina propria was disintegrated and there were hemorrhagic and ulcerative areas (Fig. 8g-i). In the FC 3 group, graded $3(3-4)$, although there was massive epithelial layer lifting from lamina propria and a few denuded villi, the mucosal structure was not disintegrated and digested (Fig. 8j-I). Mild epithelial lifting and subepithelial Gruenhagen's spaces were in the FC 6 group, which was graded I (3-4) (Fig. 8m-o). All groups were graded statistically lower than the IR group and the FC6 group showed a significant decrease compared to the FC3 group $(p<0.05)$.

\section{DISCUSSION}

The incidence of acute intestinal ischemia due to thromboembolic causes has been reported as 10.1:100.000 person years in women and 7.1:100.000 person years in men; non-occlusive reasons are excluded. The cause -mortality ratio of acute thromboembolic occlusive intestinal ischemia has been reported as 6.9:1000 autopsy in 12-year postmortem research. ${ }^{[16]}$ Moreover, due to the lack of a specific biochemical marker and pathognomonic physical examination finding, diagnosis of acute mesenteric ischemia can be delayed or misdiagnosed. Even if acute mesenteric ischemia has been correctly and promptly diagnosed, there is currently no specific therapeutic option. ${ }^{[17,18]}$

Ischemic period in AMI, after a critical duration, may lead to intestinal necrosis which can be followed by multiple organ dysfunctions. Therefore, rapid restoration of the intestinal blood flow is crucial to prevent necrosis of intestinal tissue. However, Parks and Granger, in their research published in 1986, showed that 4-hour ischemia caused less mucosal dam- age than 3-hour ischemia +1 hour reperfusion. ${ }^{[19]}$ Thus, for the first time, it was demonstrated that reoxygenation of tissue by reflow of blood had caused microcirculatory dysfunction and microvascular-microstructural damage. To sum up, it is suggested that hypoxia is responsible for mucosal lesions which occurs during ischemic period, whereas free oxygen radicals may cause mucosal damage during reperfusion. ${ }^{[20]}$

Various antioxidant compounds, such as quercetine, agmatine, resveratrol, gingerol, ginsenoside, hesperidin and proanthocyanidin, were used against ischemia-reperfusion injury in experimental acute mesenteric ischemia models. ${ }^{[21-26]}$ In addition, it has been demonstrated that some plants or its parts, such as leaves, fruits and seeds or its derivatives which has been known to have antioxidant compounds, may attenuate experimental intestinal ischemia and reperfusion damage; Origanum onites leaves oil, Parquetina nigrescens, Vaccinium myrtillus, Aronia x Prunifolia (hybrid), Citrus bergamia fruit juice, Sasa senanensis, Myrtus communis leaves oil and Nigella sativa seed oil. ${ }^{[27-34]}$

Vinson et al. have reported that figs contained $486 \mathrm{mg} / \mathrm{l} 00$ $\mathrm{g}$ total phenols as in fresh form and $326 \mathrm{mg} / \mathrm{l} 00 \mathrm{~g}$ total phenols in dried form and there was an increase in plasma total antioxidant capacity of human subjects more than $100 \%$ after consumption of a fig. ${ }^{[35]}$ The majority of the source of phenolic compounds in figs is routine, catechin, chlorogenic acid, epicatechin and gallic acid. ${ }^{[36]}$ It was shown that the total anthocyanin content of the fig fruit pulp was $1.5-15 \mu \mathrm{g} / \mathrm{g}$, resulting from 15 different anthocyanin compounds, the majority of which were cyanidine. ${ }^{[3]}$ The free fatty acids content of fig seed oil consists of linolenic, linoleic, oleic, palmitic and stearic acid, respectively. The linoleic acid content accounts for approximately $40 \%$ of the total free fatty acid concentration. Besides all these free fatty acids, Ficus carica seed oil contents tocopherol is approximately $4 \mu \mathrm{g} / \mathrm{g}$. ${ }^{[38]}$

The reactive oxygen radicals and proinflammatory cytokines, such as TNF- $\alpha$ and IL-I $\beta$, which are produced by damaged endothelial and epithelial cells during the ischemia and reperfusion period, can be recognized by local macrophages that release chemotactic agents to increase leukocyte migration to the tissue. ${ }^{[39]}$ Hence, it can be suggested that the migration of leukocytes into tissue and activation of macrophages, as a vicious cycle, led to an increase in the production of both free oxygen radicals and proinflammatory cytokines. In our study, tissue TNF- $\alpha$ and ILI- $\beta$ levels decreased in the FC6 group than the IR group, in accordance with the above-mentioned data. However, there was no statistical decrease in the FC3 group for TNF- $\alpha$ (Fig. I, 2).

MPO is a peroxidase that is stored in azurophilic granules of neutrophils, which induces the synthesis of hypochlorous acid from hydrogen peroxide. Several experimental acute mesenteric ischemia studies have shown that MPO levels increase after ischemia and reperfusion injury but can be lowered with 

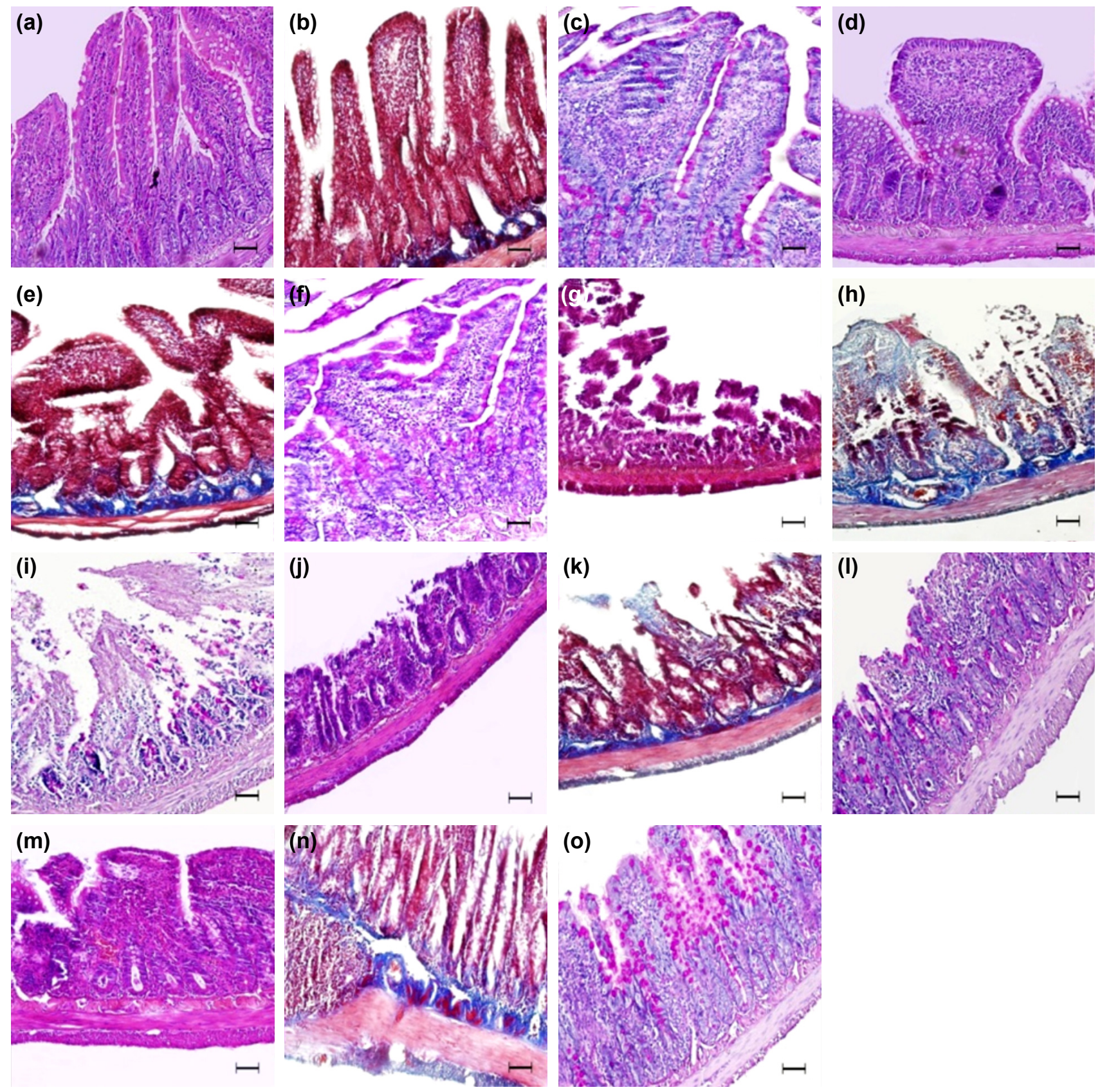

Figure 8. Representative histopathological photomicrographs of small intestine specimens. The scale bar on each photomicrograph indicates $50 \mu \mathrm{m}$. (a-c) Negative Control; Grade 0; normal intestinal tissue (respectively H\&E, Masson Trichrome, P.A.S. stained, 20X). (d-f) Sham Operated; Grade 0; normal intestinal tissue (respectively H\&E, Masson Trichrome, P.A.S. stained, 20X). (g-i) Ischemia-Reperfusion; Grade 5; digestion of mucosal layer (respectively H\&E, Masson Trichromee, P.A.S. stained, 20X).(j-I) 3 ml/kg/day Ficus Carica Seed Oil, Grade 3; massive lifting of epithelial layer- a few denuded villi (respectively H\&E, Masson Trichrome, P.A.S. stained, 20X). (m-o) 6 ml/kg/day Ficus Carica Seed Oil; Grade 1; subepithelial Gruenhagen's space at the top of the villus (respectively H\&E, Masson Trichrome, P.A.S. stained, 20X).

agents that have antinflammatory and antioxidant properties. ${ }^{[21,22,24]}$ As a result of our study, it is suggested that Ficus carica seed oil decreased tissue leukocyte migration because MPO levels of FC3 and FC6 groups were significantly lower than IR group. This decrease was statistically higher in FC6 group than FC3 group (Fig. 3).

MDA, which is a product of lipid peroxidation and prostaglandin synthesis, is an important predictor of the increase of free oxygen radicals and cellular oxidative stress. ${ }^{[40]}$ Intestinal ischemia has been reported to increase malondialdehyde levels and thus lead to cellular oxidation in several studies. ${ }^{[22,31,32,41,42]}$ These studies suggest that the antioxidant agents that they researched have decreased MDA level by preventing oxidative stress and thus prevent intestinal ischemia-reperfusion injury. In our study, MDA levels in FC3 and FC6 groups decreased significantly compared to IR group; and FC6 group showed a statistically significant decrease compared to F3 group (Fig. 4). 
SOD which converts superoxide anion to hydrogen peroxide and CAT which catalyzes the conversion of hydrogen peroxide to water are two important intracellular antioxidant key enzymes that prevent oxidant damage. ${ }^{[3]}$ Reduced glutathione (GSH), which acts like an antioxidant, is involved in the conversion of hydrogen peroxide into the water in the $\gamma$-glutamyl cycle. ${ }^{[4]}$ In our study, it has been suggested that fig oil increases antioxidant enzymes and GSH levels, which may prevent cellular oxidative damage, but there is no statistical difference between $3 \mathrm{ml} / \mathrm{kg} /$ day and $6 \mathrm{ml} / \mathrm{kg} /$ day (Fig. 5-7). Moreover, histologically, the use of Ficus carica seed oil upon intestinal ischemia and reperfusion injury decreased the grade 5 in the IR groups to 3 in the FC3 group and I in the FC6 group. The IR group had severe mucosal digestion, disintegration, hemorrhage and ulceration, but in the FC 3 group, there was mostly epithelial lifting from lamina propria and in the FC6 group, there were usually only subepithelial Gruenhagen's spaces (Fig. 8, Table 2).

\section{Conclusion}

In summary, in this study, it has been shown that intestinal ischemia-reperfusion injury increases the amount of some proinflammatory cytokines and the concentration of some enzymes originating from local and migratory cells and lipid peroxidation, decreases antioxidant enzymes and reduced glutathione amount in tissue and thus causes histological damage. It has been suggested that oral administration of fig seed oil may reverse biochemical and histopathological alterations resulting from ischemia-reperfusion injury in an experimental model of acute mesenteric ischemia in rats, probably because of its antioxidant and anti-inflammatory compounds.

\section{Acknowledgements}

This research was supported by Aydın Adnan Menderes University University Research Fund (Grant Number: TPF- I80 I6).

Ethics Committee Approval: This study approved by the Adnan Menderes University Animal Experimentation Ethics Committee (Date: 22.05.2017, Decision No: $64583101 / 2017 / 044)$.

Peer-review: Internally peer-reviewed.

Authorship Contributions: Concept: C.O., R.O.E.; Design: C.O., R.O.E.; Supervision: G.C., R.O.E.; Resource: C.O.; Materials: C.O., F.Ş.; Data: C.O., F.Ş., E.G.Y.; Analysis: C.O., F.Ş., E.G.Y., R.O.E.; Literature search: C.O.; Writing: C.O., R.O.E.; Critical revision: G.C.

Conflict of Interest: None declared.

Financial Disclosure: The authors declared that this study has received no financial support.

\section{REFERENCES}

1. Yasuhara H. Acute mesenteric ischemia: the challenge of gastroenterology. Surg Today 2005;35:185-95. [CrossRef]

2. Tilsed JV, Casamassima A, Kurihara H, Mariani D, Martinez I, Perei- ra J, et al. ESTES guidelines: acute mesenteric ischaemia. Eur J Trauma Emerg Surg 2016;42:253-70. [CrossRef]

3. Herbert GS, Steele SR. Acute and chronic mesenteric ischemia. Surg Clin North Am 2007;87:1115-34. [CrossRef]

4. Acosta S, Björck M. Modern treatment of acute mesenteric ischaemia. Br J Surg 2014;101:e100-8. [CrossRef]

5. Tabriziani H, Ahmad A, Narasimha D, Bergamaschi R, Frishman WH. A Nonsurgical Approach to Mesenteric Vascular Disease. Cardiol Rev 2018;26:99-106. Erratum in: Cardiol Rev 2018;26:218. [CrossRef]

6. Bala M, Kashuk J, Moore EE, Kluger Y, Biffl W, Gomes CA, et al. Acute mesenteric ischemia: guidelines of the World Society of Emergency Surgery. World J Emerg Surg 2017;12:38. [CrossRef]

7. Guven A, Tunc T, Topal T, Kul M, Korkmaz A, Gundogdu G, et al. Alpha-lipoic acid and ebselen prevent ischemia/reperfusion injury in the rat intestine. Surg Today 2008;38:1029-35. [CrossRef]

8. Bilbao G, Contreras JL, Eckhoff DE, Mikheeva G, Krasnykh V, Douglas JT, et al. Reduction of ischemia-reperfusion injury of the liver by in vivo adenovirus-mediated gene transfer of the antiapoptotic Bcl-2 gene. Ann Surg 1999;230:185-93. [CrossRef]

9. Parks DA. Oxygen radicals: mediators of gastrointestinal pathophysiology. Gut 1989;30:293-8. [CrossRef]

10. Yamamoto S, Tanabe M, Wakabayashi G, Shimazu M, Matsumoto K, Kitajima M. The role of tumor necrosis factor-alpha and interleukin-1beta in ischemia-reperfusion injury of the rat small intestine. J Surg Res 2001;99:134-41. [CrossRef]

11. Çalişkan O, Polat AA. Phytochemical and antioxidant properties of selected fig (Ficus carica L.) accessions from the eastern Mediterranean region of Turkey. Sci Horti 2011;128:473-8. [CrossRef]

12. Veberic R, Colaric M, Stampar F. Phenolic acids and flavonoids of fig fruit (Ficus carica L.) in the northern Mediterranean region. Food Chem 2008;106:153-7. [CrossRef]

13. Badgujar SB, Patel VV, Bandivdekar AH, Mahajan RT. Traditional uses, phytochemistry and pharmacology of Ficus carica: a review. Pharm Biol 2014;52:1487-503. [CrossRef]

14. Saoudi M, El Feki A. Protective role of ficus carica stem extract against hepatic oxidative damage induced by methanol in male wistar rats. Evid Based Complement Alternat Med 2012;2012:150458. [CrossRef]

15. Chiu CJ, McArdle AH, Brown R, Scott HJ, Gurd FN. Intestinal mucosal lesion in low-flow states. I. A morphological, hemodynamic, and metabolic reappraisal. Arch Surg 1970;101:478-83. [CrossRef]

16. Acosta S, Ogren M, Sternby NH, Bergqvist D, Björck M. Incidence of acute thrombo-embolic occlusion of the superior mesenteric artery--a population-based study. Eur J Vasc Endovasc Surg 2004;27:145-50.

17. Lauterbach M, Horstick G, Plum N, Lotz J, Lauterbach E, Weilemann LS, et al. C1-esterase inhibitor reverses functional consequences of superior mesenteric artery ischemia/reperfusion by limiting reperfusion injury and restoring microcirculatory perfusion. Shock 2007;27:75-83.

18. Prakash VS, Marin M, Faries PL. Acute and Chronic Ischemic Disorders of the Small Bowel. Curr Gastroenterol Rep 2019;21:27. [CrossRef]

19. Parks DA, Granger DN. Contributions of ischemia and reperfusion to mucosal lesion formation. Am J Physiol 1986;250:G749-53. [CrossRef]

20. Vollmar B, Menger MD. Intestinal ischemia/reperfusion: microcirculatory pathology and functional consequences. Langenbecks Arch Surg 2011;396:13-29. [CrossRef]

21. Tóth Š, Jonecová Z, Čurgali K, Maretta M, Šoltés J, Švaňa M, et al. Quercetin attenuates the ischemia reperfusion induced COX-2 and MPO expression in the small intestine mucosa. Biomed Pharmacother 2017;95:346-54. [CrossRef]

22. Turan I, Ozacmak HS, Ozacmak VH, Barut F, Araslı M. Agmatine attenuates intestinal ischemia and reperfusion injury by reducing oxidative stress and inflammatory reaction in rats. Life Sci 2017;189:23-8. [CrossRef]

23. Huang X, Zhao W, Hu D, Han X, Wang H, Yang J, et al. Resveratrol 
efficiently improves pulmonary function via stabilizing mast cells in a rat intestinal injury model. Life Sci 2017;185:30-7. [CrossRef]

24. Li Y, Xu B, Xu M, Chen D, Xiong Y, Lian M, et al. 6-Gingerol protects intestinal barrier from ischemia/reperfusion-induced damage via inhibition of p38 MAPK to NF-KB signalling. Pharmacol Res 2017;119:137-48.

25. Jiang Y, Zhou Z, Meng QT, Sun Q, Su W, Lei S, et al. Ginsenoside Rb1 treatment attenuates pulmonary inflammatory cytokine release and tissue injury following intestinal ischemia reperfusion injury in mice. Oxid Med Cell Longev 2015;2015:843721. [CrossRef]

26. Sizlan A, Guven A, Uysal B, Yanarates O, Atim A, Oztas E, et al. Proanthocyanidin protects intestine and remote organs against mesenteric ischemia/reperfusion injury. World J Surg 2009;33:1384-91. [CrossRef]

27. Canbek M, Uyanoglu M, Bayramoglu G, Senturk H, Erkasap N, Koken $T$, et al. Effects of carvacrol on defects of ischemia-reperfusion in the rat liver. Phytomedicine 2008;15:447-52. [CrossRef]

28. Akinrinmade FJ, Akinrinde AS, Soyemi OO, Oyagbemi AA. Antioxidant Potential of the Methanol Extract of Parquetina nigrescens Mediates Protection Against Intestinal Ischemia-Reperfusion Injury in Rats. J Diet Suppl 2016;13:420-32. [CrossRef]

29. Jakesevic M, Xu J, Aaby K, Jeppsson B, Ahrné S, Molin G. Effects of bilberry (Vaccinium myrtillus) in combination with lactic acid bacteria on intestinal oxidative stress induced by ischemia-reperfusion in mouse. J Agric Food Chem 2013;61:3468-78. [CrossRef]

30. Jakesevic M, Aaby K, Borge GI, Jeppsson B, Ahrné S, Molin G. Antioxidative protection of dietary bilberry, chokeberry and Lactobacillus plantarum HEAL19 in mice subjected to intestinal oxidative stress by ischemia-reperfusion. BMC Complement Altern Med 2011;11:8. [CrossRef]

31. Impellizzeri D, Cordaro M, Campolo M, Gugliandolo E, Esposito E, Benedetto F, et al. Anti-inflammatory and Antioxidant Effects of Flavonoid-Rich Fraction of Bergamot Juice (BJe) in a Mouse Model of Intestinal Ischemia/Reperfusion Injury. Front Pharmacol 2016;7:203. [CrossRef]

32. Kurokawa T, Itagaki S, Yamaji T, Nakata C, Noda T, Hirano T, et al. Antioxidant activity of a novel extract from bamboo grass (AHSS) against ischemia-reperfusion injury in rat small intestine. Biol Pharm Bull 2006;29:2301-3. [CrossRef]
33. Jabri MA, Hajaji S, Marzouki L, El-Benna J, Sakly M, Sebai H. Human neutrophils ROS inhibition and protective effects of Myrtus communis leaves essential oils against intestinal ischemia/reperfusion injury. RSC Adv 2016;6:16645-55. [CrossRef]

34. Tayman C, Cekmez F, Kafa IM, Canpolat FE, Cetinkaya M, Uysal S, et al. Beneficial effects of Nigella sativa oil on intestinal damage in necrotizing enterocolitis. J Invest Surg 2012;25:286-94. [CrossRef]

35. Vinson JA, Zubik L, Bose P, Samman N, Proch J. Dried fruits: excellent in vitro and in vivo antioxidants. J Am Coll Nutr 2005;24:44-50. [CrossRef]

36. Solomon A, Golubowicz S, Yablowicz Z, Grossman S, Bergman M, Gottlieb HE, et al. Antioxidant activities and anthocyanin content of fresh fruits of common fig (Ficus carica L.). J Agric Food Chem 2006;54:7717-23.

37. Wang Z, Cui Y, Vainstein A, Chen S, Ma H. Regulation of Fig (Ficus carica L.) fruit color: metabolomic and transcriptomic analyses of the flavonoid biosynthetic pathway. Front Plant Sci 2017;8:1990. [CrossRef]

38. Icyer NC, Toker OS, Karasu S, Tornuk F, Kahyaoglu T, Arici M. Microencapsulation of fig seed oil rich in polyunsaturated fatty acids by spray drying. J Food Meas Charact 2017;11:50-7. [CrossRef]

39. Sadik CD, Kim ND, Luster AD. Neutrophils cascading their way to inflammation. Trends Immunol 2011;32:452-60. [CrossRef]

40. Marnett LJ. Lipid peroxidation-DNA damage by malondialdehyde. Mutat Res 1999;424:83-95. [CrossRef]

41. Liu KX, Wu WK, He W, Liu CL. Ginkgo biloba extract (EGb 761) attenuates lung injury induced by intestinal ischemia/reperfusion in rats: roles of oxidative stress and nitric oxide. World J Gastroenterol 2007;13:299-305. [CrossRef]

42. Itagaki S, Oikawa S, Ogura J, Kobayashi M, Hirano T, Iseki K. Protective effects of quercetin-3-rhamnoglucoside (rutin) on ischemia-reperfusion injury in rat small intestine. Food Chem 2010;118:426-9. [CrossRef]

43. Ighodaro OM, Akinloye OA. First line defence antioxidants-superoxide dismutase (SOD), catalase (CAT) and glutathione peroxidase (GPX): Their fundamental role in the entire antioxidant defence grid. Alexandria Med J 2018;54:287-93. [CrossRef]

44. Meister A. Glutathione metabolism. Methods Enzymol 1995;251:3-7.

\section{DENEYSEL ÇALIŞMA - ÖZ}

\section{Akut mezenterik iskemi sıçan modelinde Ficus carica çekirdek yağının iskemi reperfüzyon hasarı üzerine koruyucu etkileri \\ Dr. Cenk Orak, ${ }^{1}$ Dr. Ferhat Şirinyıldız, ${ }^{1}$ Dr. Esra Gökmen Yılmaz, ${ }^{2}$ Dr. Gökhan Cesur, ${ }^{1}$ Dr. Rauf Onur Ek ${ }^{1}$}

\section{${ }^{1}$ Aydın Adnan Menderes Üniversitesi Tıp Fakültesi, Fizyoloji Anabilim Dalı, Aydın}

${ }^{2}$ Aydın Adnan Menderes Üniversitesi Tıp Fakültesi, Histoloji ve Embriyoloji Anabilim Dalı, Aydın

AMAÇ: Akut mezenterik iskemi neticesinde gelişen iskemi reperfüzyon hasarındaki histopatolojik bozulmanın temel sorumlusu serbest oksijen radikalleri ve proenflamatuvar sitokinlerin artısılır. Ficus carica ve çeşitli kısımlarının antioksidan ve antienflamatuvar özellikler gösterdiği geçmiş çalışmalarda bildirilmiştir. Bu çalışmada da Ficus carica çekirdek yağının, sıçanlarda intestinal iskemi reperfüzyon hasarı üzerine etkilerini incelemek amaçlanmıştır.

GEREÇ VE YÖNTEM: Elli adet Wistar albino sıçan beş eşit gruba bölündü. Negatif kontrol (NC), sham-operated (Sham), iskemi ve reperfüzyon (IR), 3 ml/kg/gün Ficus carica çekirdek yağı (FC3), 6 ml/kg/gün Ficus carica çekirdek yağı (FC6). IR, FC3 ve FC6 gruplarına iskemi ve reperfüzyon prosedürü $45+120 \mathrm{dk}$ boyunca uygulandı. Sham grubu sıçanlar yalnızca abdominal orta hat laparotominin ardından $165 \mathrm{dk}$ boyunca bekletildi. BULGULAR: Proenflamatuvar sitokinler olan IL-I $\beta$ ve TNF $\alpha$ doku seviyeleri FC6 grubunda IR grubuna gore anlamlı derecede düşüktü $(p<0.05)$ FC6 ve FC3 gruplarının MDA ve MPO düzeyleri IR grubuna kıyasla düşük olup, FC6 grubundaki düşüş FC3 grubundaki düşüşten istatistiksel olarak daha fazlaydı $(p<0.05)$. FC6 ve FC3 gruplarını her ikisinde de SOD ve CAT enzimleri ile indirgenmiş glutatyon seviyeleri IR grubuna kıyasla düşük olsa da FC3 ve FC6 grupları arasında anlamlı fark yoktu $(p<0.05)$. Histopatolojik olarak FC3 ve FC6 gruplarını her ikisi de IR grubundan düşük, FC6 grubu ise FC3 grubundan daha düşük bir skorla evrelendi $(p<0.05)$.

TARTIŞMA: İncir çekirdeği yağının oral kullanımı, olasılıkla antioksidan ve antienflamatuvar özellikleri sebebiyle, sıçanlarda akut mezenterik iskemi modeline bağlı gelişen iskemi reperfüzyon hasarındaki biyokimyasal ve histopatolojik bulguları tersine çevirebilmektedir. Anahtar sözcükler: Akut mezenterik iskemi; antioksidan; Ficus carica; iskemi reperfüzyon hasarı.

Ulus Travma Acil Cerrahi Derg 2021;27(4):402-409 doi: 10.14744/tjtes.2020.76767 